\title{
Analyzing Relationship Between Unemployment and Growth For Selected OECD Countries Through Panel Data
}

\author{
Ahmet Tayfur AKCAN* \\ Volkan ALPTEKİN ${ }^{* * *}$ \\ Kubilay Çağrı YILMAZ**
}

\begin{abstract}
Being able to examine the research question of this study, whether there is a correlation between unemployment and growth for selected certain OECD member countries, panel data econometrics have been practiced. In the light of empirical findings, while there is a relationship from unemployment to growth, on the other hand, there is no link from growth to unemployment has been reported. Although there is somehow a harmony with other studies existing in the literature in this area, there has been still some conflicts with the rest of them. In some of the reviews, conversely ours, the link from growth to unemployment has been explicitly reported. It is thought that the distinction between this study and other conflicting ones might have arisen from the sample or the method used. It was concluded that there would be no clear dynamics of the relationship between unemployment and growth. Therefore, it was observed that the selected sample and the method used were directly effective on the results.
\end{abstract}

Key Words: Economic Growth, Unemployment, Panel Data Econometrics

Introduction

JEL Classification: O10, E24, C32

\section{Seçilmiş OECD Ülkelerinde İşsizlik ve Büyüme Arasındaki İlişskinin Panel Veri Yöntemiyle Analizi}

\begin{abstract}
$\ddot{O} Z$
OECD ülkelerinden oluşan örneklem grubu için işsizlik ve büyüme arasındaki ilişkiyi araştırma sorusu olarak konu alınan bu çalışmada panel veri yöntemi yardımıyla ekonometrik olarak incelenmiştir. Ampirik bulgular ışığında işsizlik değişkenin büyüme ile aralarında bir ilişki raporlanırken, söz konusu ilişkinin büyümeden işsizliğe doğru çalışmadiğı görülmüş̧ür. Bu yönüyle değerlendirildiğinde literatürde yer alan çalışmaların büyük bir bölümü ile ayn yönde sonuçlar vermersiyle beraber çalışma, farklı sonuçların raporlandiğı çalışmalardan örneklem farklılığ işsizlik ve büyüme arasındaki iliş̧kinin net bir dinamiğinin olamayacağı sonucuna ulaşılmıştır. Buna bağll olarak da seçilen örneklem ve kullanılan yöntemin sonuçlar üzerinden doğrudan etkili olduğu gözlenmiştir.
\end{abstract}

Anahtar Kelimeler: Ekonomik büyüme, Isssizlik, Panel veri Ekonometrisi

JEL Sinıflandırması: O10, E24, C32

\footnotetext{
*. Dr. Öğr. Üyesi, Necmettin Erbakan Üniversitesi, Uygulamalı Bilimler Yüksekokulu, Konya. ORCID bilgisi: 0000-0001-8210-7327

** Dr. Öğr. Üyesi, Manisa Celal Bayar Üniversitesi, işletme Fakültesi, Ekonomi ve Finans Bölümü, Manisa, ORCID bilgisi: 0000-0002-2489-9968

${ }^{* * *}$ Prof. Dr, İzmir Kâtip Çelebi Üniversitesi İktisadi ve İdari Bilimler Fakültesi, İktisat Bölümü, İzmir, ORCID bilgisi: 0000-0002-4579-6802
} 


\section{INTRODUCTION}

The Mortgage Crisis starting in the US and gradually rising evolved to the global financial crisis has made the three primary economic objectives in common throughout the world. These goals can be said as follows; controlling inflation, achieving sustainable growth, and reducing the rate of unemployment, respectively. After experienced such an extreme dimensioned crisis. It is inevitable that the studies pertaining to the global financial crisis refer to these primary goals.

Economic growth has been on the agenda of all economic fractions since the mercantilism first seen on the historical stage so far. While mercantilists view the economic structure as valuable metals, however, physiocrats consider that the vital building block of the economy has been agricultural production. The classical economics that was adopted as a branch of science by publishing the book "Wealth Of Nations" in 1776 has approached economic growth via supply-led policies. Nevertheless, Karl Marx has viewed the primary source of the economy as the labor factor and preferred to model the economic growth by labor-led paradigms. Keynesian approach appearing with the Great Depression has described the economic growth through demand-led policies on the contrary to classical economics. While economic growth has been depicted as a net increase in capital stock (Harrod-Domar Model) in Post Keynesian School, It has been enlightened by technological improvement (Solow Model) proposed tech-based policies in the Neoclassical paradigm. "Unemployment studies" is one of the top research fields in the, particularly macroeconomic literature. Even though there are a few reviews that have been performed in an academical way, it remains one of the most problematic issues that need to be solved ahead of economics practitioners.

World Labor Organization (WLO) was founded for implementing an exact harmony with the developed countries and improving working conditions to catch up with them. According to the report issued by WESO, it is predicted that overall macroeconomic indicators tend to get worse during the 2015-2020 period regarding unemployment, growth, and inequalities (Pinar et al., 2016: 9). Accordingly, the importance of employment and particularly unemployment is going be much more vital for economies. Especially after the mortgage crisis in 2008, "the unemployment" has been a widespread problematic issue not for merely the economies facing directly with this crisis but for the rest of them as well. Therefore all of the countries except none of them have been fighting against unemployment even today.

\section{THEORETICAL FRAMEWORK}

Arthur M. Okun's research is by far the most pioneer study that concerned over the relationship between unemployment and growth issue. In the study, Arthur M. Okun (1962), examined the condition of aggregate output in the full employment circumstances. Since the research has been the earliest inquiry investigating the link between unemployment and growth, the 
coefficient and the regression equation were recognized "Okun Coefficient" and "Okun's Law" respectively.

Arthur M. Okun (1962) drew attention to the correlation between unemployment and output (growth) as follows (Barış1k et al.; 2010, 91);

$$
\mathrm{U}=\mathrm{U}^{*}-\beta\left(\frac{Y-Y^{*}}{Y^{*}}\right)
$$

In this equation, $\mathrm{U}, \mathrm{U}^{*}, \mathrm{Y}$, and $\mathrm{Y}^{*}$ corresponds to the unemployment rate, the natural rate of unemployment, actual GDP, and Potential GDP respectivrly. In his study, Arthur M. Okun (1962) investigated the rate of unemployment in periods. It was put forward that the unemployment series did not have a trend during the years before World War II, it was averagely $4,5 \%$ between 1947 - 1953. It was computed in a condition that the rate of unemployment rises by $1 \%$, potential GDP will reduce by 3,3\% during the years 1947-1960. Along these lines the rate of unemployment increases by 1 $\%$, potential GDP will decrease by 3\% during the years 1954-1962.

It was computed that in a condition that the rate of unemployment rises by $1 \%$, potential GDP will reduce by 3,3\% during the years 1947-1960 and in a situation that the rate of unemployment increases by 1\% GDP will fall by 3\% during the years 1954-1962. It was stated that the coefficients computed in the study might differ from sample to sample regarding labor supply, the distinction over working hours and efficiency. These three factors constitute the constraint of the study.

According to Arthur M. Okun, changing the rate of employment does not simply occur. The requisites in the contract, technological factors, transaction costs, experiences, skills, and motivation are the underlying reasons (Okun, 1962; 6-7). Particularly in any agreement quitting or expelling jobs are so dissuasive for both sides. This situation and speeding up in technological developments will eventually cause rigidity in the labor force. The newly hired employees, for substituting the effort performed by quitting and dismissing labor force, are supposed to catch up with the developments in technology and to keep up with the improvements, but it is somehow impossible to fulfill. Therefore labor force market is getting rigidity. In the same manner, the experience that the labor force gains along the working hours will cause the labor force to appreciate. This appreciation will not let the laborforce dismissed simply. Additionally, the fact that laid-off employees can be expected to demoralize the remaining ones is one of the most common rigidity factors in the labor force market.

Consequently, since the labor force market per se has rigidity concerning entering and quitting, the rate of unemployment will not amend in an easy way.

\section{LITERATURE}

The table summurizes some of the selected studies about unemployment and growth relationship. 
Ahmet Tayfur Akcan \& Kubilay Çağrı Yılmaz \& Volkan Alptekin / Analyzing Relationship Between Unemployment and Growth For Selected OECD Countries Through Panel Data

\begin{tabular}{|c|c|c|c|c|c|c|c|c|c|c|c|c|}
\hline 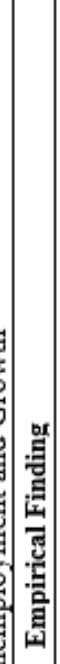 & 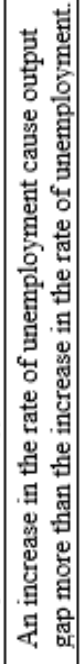 & 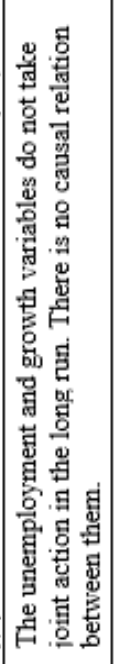 & 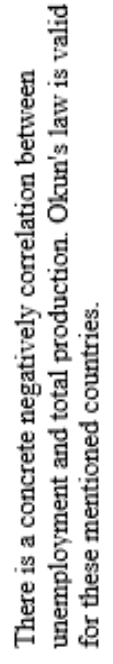 & 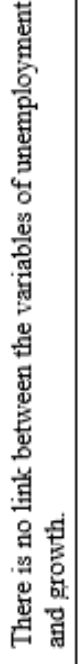 & 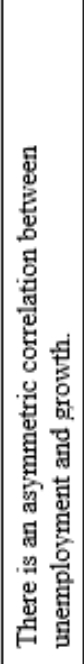 & 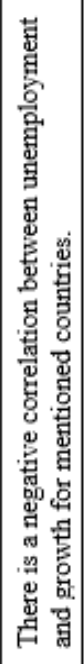 & 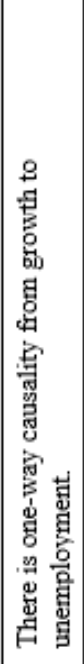 & 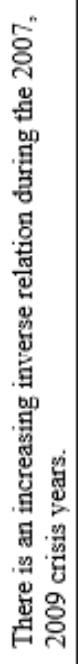 & 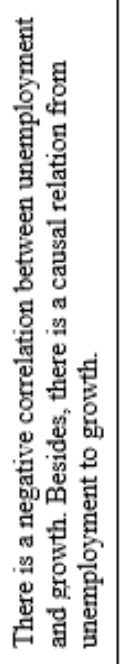 & 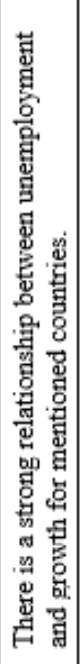 & 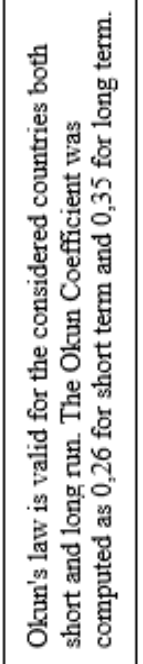 & 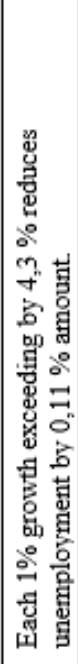 \\
\hline 夠 & 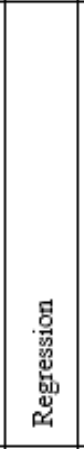 & 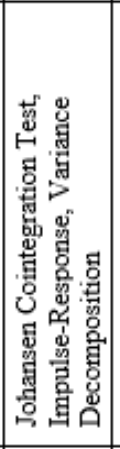 & 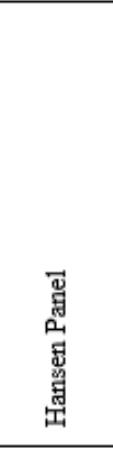 & 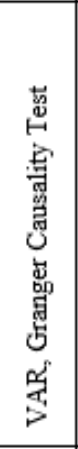 & 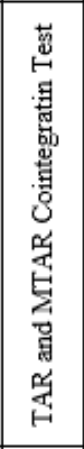 & 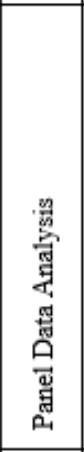 & 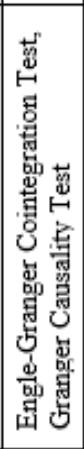 & 娄 & 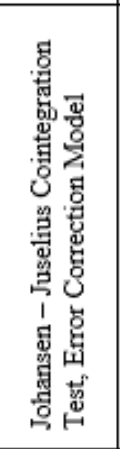 & 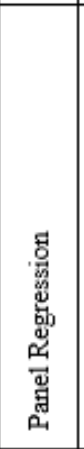 & 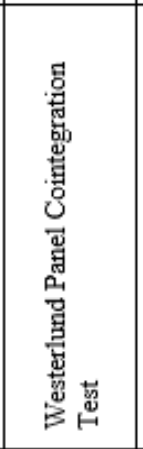 & 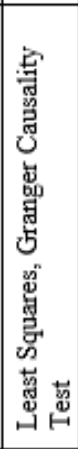 \\
\hline 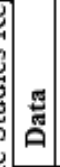 & $\begin{array}{l}\frac{8}{2} \\
\frac{1}{8} \\
\frac{1}{2}\end{array}$ & 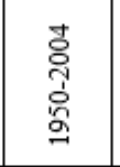 & 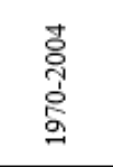 & 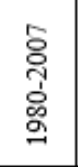 & 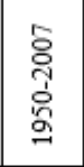 & 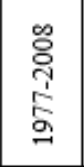 & $\begin{array}{l}\text { 응 } \\
\text { ণิ } \\
\text { 응 }\end{array}$ & 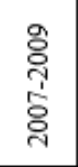 & $\begin{array}{l}\stackrel{ }{\circ} \\
\text { 응 } \\
\text { 。 }\end{array}$ & 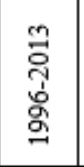 & 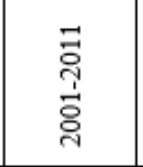 & 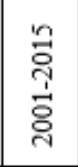 \\
\hline 㤩 & 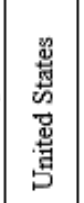 & 密 & 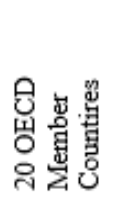 & 密 & 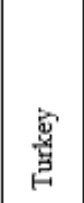 & 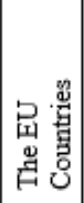 & 密 & 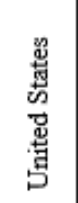 & $\begin{array}{c}\text { 密 } \\
\text { 总 }\end{array}$ & $\begin{array}{l}\text { 总 } \\
\text { 悬 } \\
\text { ठ } \\
\text { 田 }\end{array}$ & 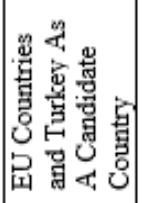 & $\begin{array}{l}\text { 密 } \\
\text { 总 } \\
\text { 晋 }\end{array}$ \\
\hline 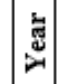 & 용 & ষ্ণ & 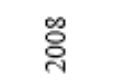 & ठ্ণે & 음 & $\overrightarrow{\overrightarrow{0}}$ & 궁 & $\stackrel{\overrightarrow{0}}{\overrightarrow{0}}$ & 류 & 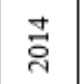 & 范 & 율 \\
\hline 总 & 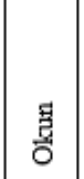 & 宽 & 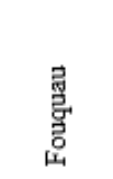 & 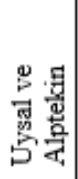 & 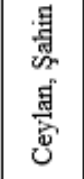 & $\begin{array}{l}\text { 㖊 } \\
\text { 昜 } \\
\text { 量 }\end{array}$ & 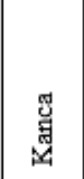 & 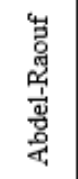 & 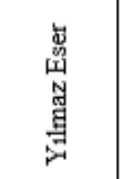 & 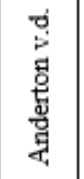 & 荛 & \\
\hline
\end{tabular}




\begin{tabular}{|c|c|c|c|c|c|c|c|c|c|c|c|}
\hline 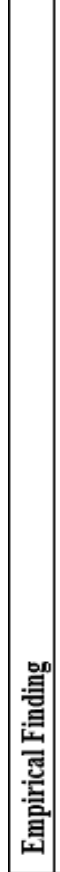 & 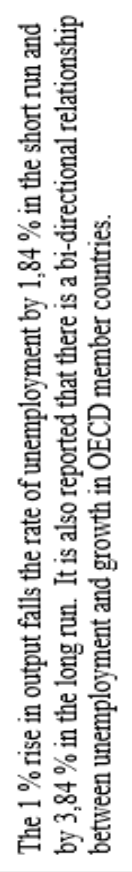 & 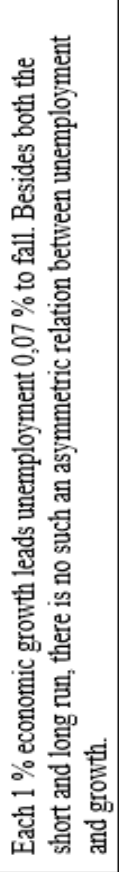 & 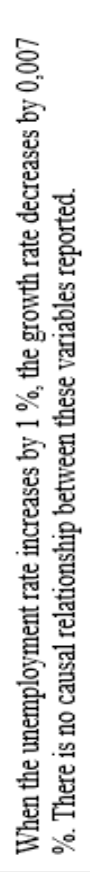 & 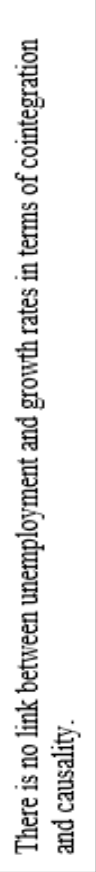 & 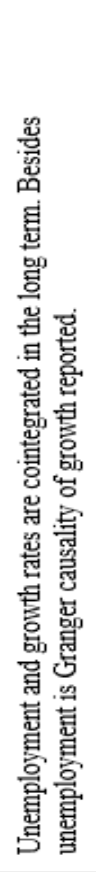 & 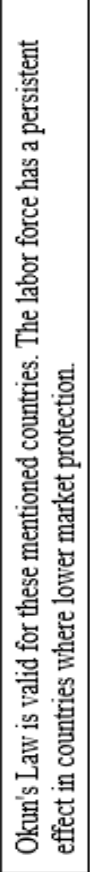 & 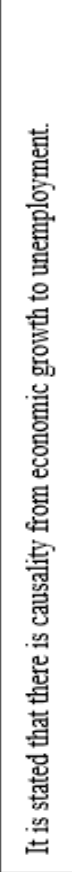 & 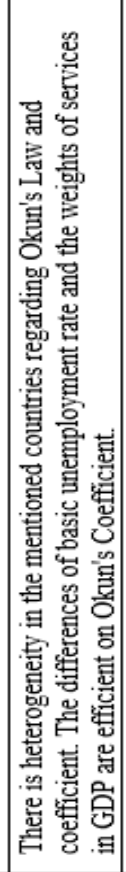 & 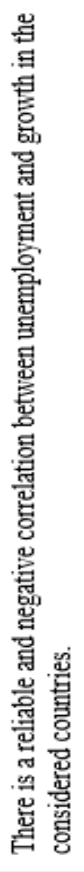 & 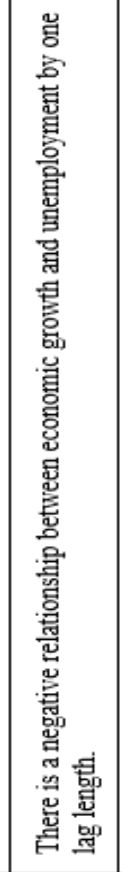 & 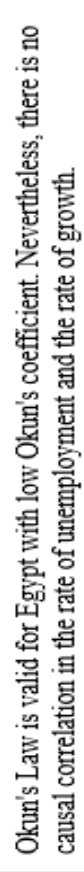 \\
\hline 胥 & 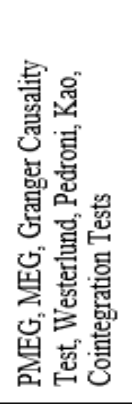 & 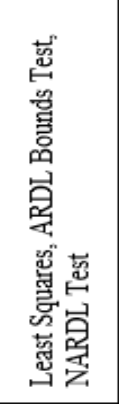 & 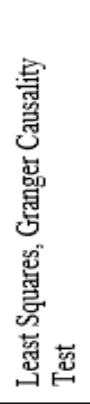 & 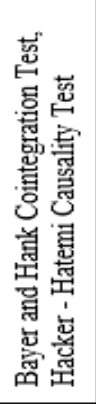 & 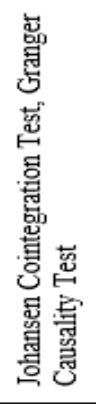 & 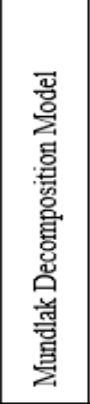 & 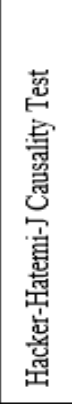 & 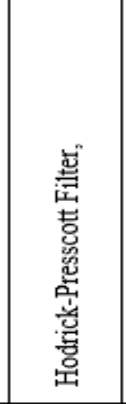 & 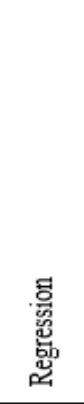 & 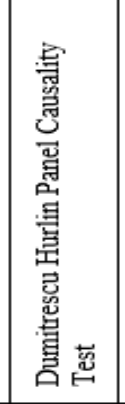 & 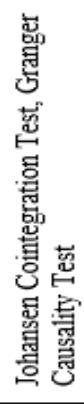 \\
\hline 营 & $\begin{array}{l}\text { 芦 } \\
\text { ণิ } \\
\text { 号 }\end{array}$ & 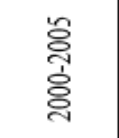 & $\begin{array}{l}\text { 芌 } \\
\text { ஸे }\end{array}$ & 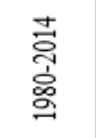 & $\begin{array}{l}\text { पें } \\
\text { ণे }\end{array}$ & $\begin{array}{l}\text { 节 } \\
\text { ஸे }\end{array}$ & $\begin{array}{l}\text { 䓂 } \\
\text { ஸे }\end{array}$ & $\begin{array}{l}\text { 年 } \\
\text { ণे } \\
\text { 。 }\end{array}$ & 咨 & 咢 & $\begin{array}{l}\text { 을 } \\
\text { 응 }\end{array}$ \\
\hline 章 & $\begin{array}{l}\text { 悬 } \\
\text { 它 } \\
\text { 岁 }\end{array}$ & $\begin{array}{l}\text { 总 } \\
\text { 音 }\end{array}$ & 密 & 密 & 密 & $\begin{array}{l}\text { 总 } \\
\text { 害 } \\
\text { 㞻 }\end{array}$ & 兽 & 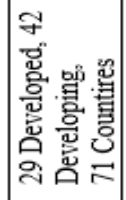 & 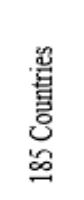 & 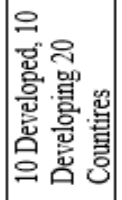 & $\begin{array}{l}\text { 蒙 } \\
\text { 留 }\end{array}$ \\
\hline$\stackrel{\Xi}{\Xi}$ & 음 & 음 & 음 & 음 & 음 & 음 & 을 & 음 & 롱 & 혹 & $\stackrel{\infty}{\stackrel{\circ}{\circ}}$ \\
\hline 章 & 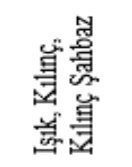 & 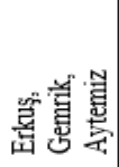 & $\mathscr{A}$ & 文 & 5 & 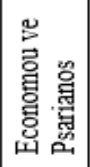 & 总离 & 言 & $\begin{array}{l}\text { : } \\
\text { 염 }\end{array}$ & 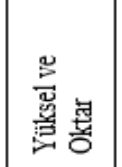 & \\
\hline
\end{tabular}




\section{DATA SET}

The relationship between unemployment and economic growth for OECD member countries for the 1991-2014 period was investigated by using annual data.

Figure 1. Time Series Graphs Of Unemployment and Economic Growth According To Nomenclature of Territorial Units for Statistics
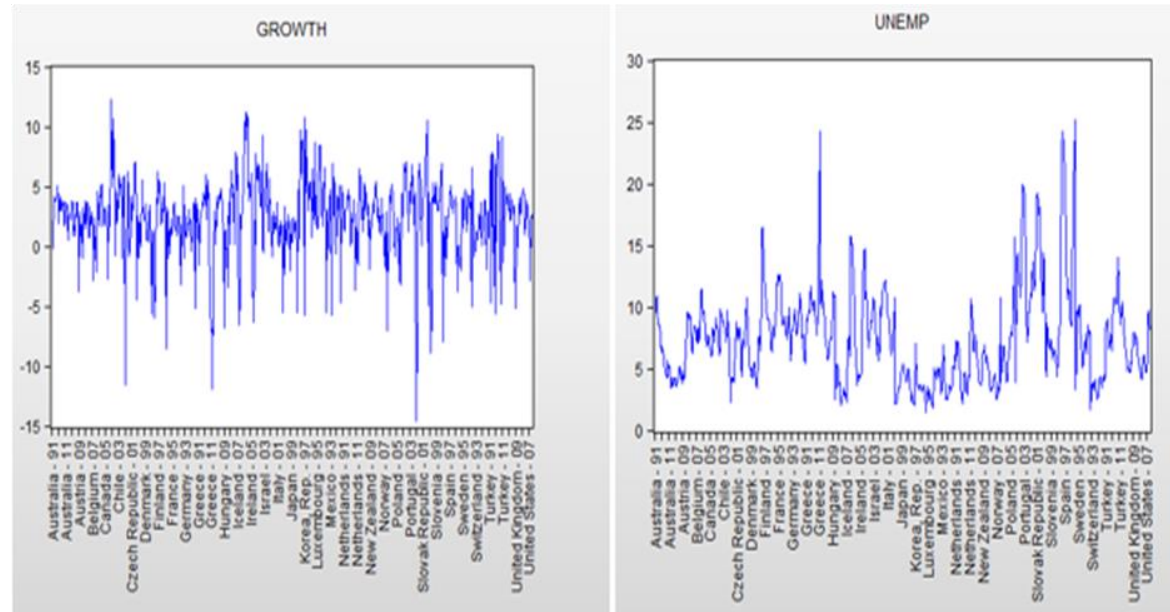

Source: World Bank (15.01.2015)

The relationship between unemployment and economic growth for selected thirty-three OECD member countries can be seen through the times series data. The graph is not able to exhibit the relational condition between the countries mentioned above not because of lack of information but because of having several different aspects just like socio-economic inequalities.

\section{METHODOLOGY}

Distinctive data species are used in economics studies. These data species can be examined just with appropriate models. It can be analyzed various research with times series, cross-section, and vertical section series. The methodology used for estimating the relationship between economic variables by using a cross-sectional set having a time dimension is called panel data analysis. In this analysis, there is obtained a series having both time and cross-section dimension by congregating time and cross-section series together. In recent times a data series has been set by assembling both these two series.

Panel data analysis has also been adopted in this study. Panel data analysis has two dimensions consisting of spatial (i) and temporal (t). While firms, countries, and commodities are constituting the spatial part, periodic observation of a variable set is constituting the temporal part (Baltagi, 1995). The advantages of applying panel data analysis can be specified as follows;

$>\quad$ Since the panel data analysis is associated with people, firms, etc. in time, it is inevitable that there is a heterogeneous relationship between them. 
Panel data provide more informational data, variability, degree of freedom, less collinearity among the variables, and a much more effective model by assembling the time series of observations.

Since panel data deals with reiterating cross-sectional observation, it is an appropriate model for "changing dynamics"

$>\quad$ Panel data analysis measures the effects that can not observable just in time series and cross-sectional series.

$>\quad$ Panel data analysis enables studying on more complex models (Gujurati, 2033: 638).

It can be viewed as a standard panel data model below;

$Y_{i t}=\beta_{1 i t}+\beta_{2 i t} X_{2 i t}+\ldots .+\beta_{k i t} X_{k i t}+e_{i t} \quad i=1 \ldots . . N \quad t=1 \ldots . T$

In this equation, $\mathrm{N}$ corresponds units, and $\mathrm{t}$ corresponds to a time when $\mathrm{Y}$ is a dependent variable, taking different values from unit to unit, from a period to consecutive period, it is expressed as the two different subscripts that consist of (i) for cross-section period and (t) for time period. This global model allows fixed and regression parameters are being allocated in each period and unit.

\subsection{Panel Unit Root Tests}

Granger and Newbold (1974) stated that, in case of working on nonstable variables, the regression resolution would be unsafe, and there would be spurious regression in examined variables. It's thus essential to control the stability before the regression resolution. There are several leading and primary methodologies offering unit root testing in panel data models which are; Levin and Lin (1993,1994), Breitung and Meyer (1994), Quah (1994), Maddala and Vu (1999), Hadri (2000) and Im Pesaran and Shin (IPS) (2003). Recently Levin and Lin and (IPS) unit root tests have been commonly performed among the studies examining the relationship with panel data analysis. In this study (IPS) unit root test regime has been deployed. In (IPS) unit root test, it is looked in average ADF test statistics by computing ADF for every each unit in a panel model. These panel unit root tests investigate whether the time series is stable $\left(y_{i t}\right)$ by equalizing the $(\beta)$ coefficient in the equation below to zero just like in Augmented Dickey-Fuller Test.

$$
\Delta y_{i, t}=\alpha_{t}+\beta_{i} y_{i, t-1}+\sum_{j=1}^{p_{i}} P_{i, j} \Delta y_{i, t-j}+\varepsilon_{i, t} \quad y_{i, t}(i=1, \ldots, N, t=1, \ldots, T)
$$

Since in panel unit root tests, there is plenty of cross-section, there are more than one $(\beta)$ exists. In the IPS test, the null hypothesis is $\left(\mathrm{H}_{0}: \beta \mathrm{i}=0\right)$ for all (i) and the alternative hypothesis is $\left(\mathrm{H}_{1}: \beta \mathrm{i}<0\right)$. T-bar stat is used for testing the null hypothesis in IPS.

$$
\sqrt{N}\left(\bar{t}-E\left(\tau_{\ell} \mid \beta_{t}=0\right) /\left(\operatorname{Var}\left(\tau_{\ell} \mid \beta_{t}=0\right)^{\frac{1}{2}} \sim N(0,1)\right.\right.
$$




$$
\begin{array}{r}
\tau_{\ell}=\frac{\partial_{t}}{\partial_{\beta_{t}}} \text { ve } \bar{t}=\frac{1}{N} \sum_{t=1}^{N} \tau_{\ell} \\
E\left(\tau_{\ell} \mid \beta_{t}=0\right) \\
\operatorname{Var}\left(\tau_{\ell} \mid \beta_{t}=0\right)
\end{array}
$$

The best advantages of IPS test can be specified as follows; computing different $(\beta)$ for every each cross-section, Letting imbalanced panels use, letting different lags in ADF Tests computed for cross-sections (Baltagi, 2005).

Panel unit root tests have asymptotic distribution. When panel root tests are compared to traditional ones, the significance of analysis is getting robust; hence is because new unit root tests have been offered recently. Two of these tests (IPS) and Maddala Wu (1997) have been preferred to deployed in this paper.

The stochastic process composed in IPS unit root test can be obtained as below;

$$
\begin{gathered}
\Delta y_{i t}=\alpha_{i}+\delta_{i} y_{i t-1}+\zeta_{i t} \\
H_{0}: \delta_{i}=0 \\
H_{1}: \delta_{i} \triangleleft 0 \quad i=1, \ldots . ., \mathrm{N}_{1} \\
\delta_{i}=0 i=\mathrm{N}_{1}
\end{gathered}
$$

$\mathrm{N}$ and $\mathrm{T}$ correspond to cross-section and time series, respectively. In a first degree stochastic process can be defined as follows;

$$
\Delta y_{i t}=\alpha_{i}+\delta_{i} y_{i t}+\zeta_{i t}
$$

The hypothesis below is used to test unit root.

$$
\begin{aligned}
& H_{0}: \delta_{i}=0 \\
& H_{1}: \delta_{i} \triangleleft 0 \quad i=1, \ldots \ldots, \mathrm{N}_{1} \\
& \delta_{i}=0 \quad i=\mathrm{N}_{1}
\end{aligned}
$$

IPS employs t-bar statistic to test the null hypothesis.

$$
\begin{aligned}
& \bar{t}_{N T}=N^{-1} \sum_{i=1}^{N} t_{i T}\left(p_{i}, \theta_{i}\right) \\
& \psi_{\bar{t}}=\frac{\sqrt{N}\left\{\bar{t}_{N T}-N^{-1} \sum_{i=1}^{N} E\left[t_{i T}\left(p_{i}, 0\right) \mid \delta_{i}=0\right]\right\}}{\sqrt{N^{-1} \sum_{i=1}^{N} \operatorname{Var}\left[t_{i T}\left(p_{i}, 0\right) \mid \delta_{i}=0\right]}} \\
& t_{i T}\left(p_{i}, i\right) \theta, \delta_{i}=0
\end{aligned}
$$


T-statistics examines the $t_{i T}\left(p_{i}, i\right) \theta, \delta_{i}=0 \quad$ hypothesis. $E\left[t_{i T}\left(p_{i}, 0\right) \mid i 0\right] \delta=$ and $\operatorname{Var}\left[t_{i T}\left(p_{i}, 0\right) \mid i 0\right] \delta=$ values are obtained by 50.000 reiterated simulations for different values of $\mathrm{T}$ and $\mathrm{p}$.

Fisher's nonparametric test statistic is used in the study for the ADF test offered by Maddala and Wu (1997).

$$
\lambda_{i}=-2 \sum_{i=1}^{N} \ln \pi_{i}
$$

In equation (7), this statistic has two degrees of freedom (x2) distribution.

$$
\Delta y_{i t}=\alpha_{i}+\delta_{i} y_{i t-1}+\sum_{j=1}^{p_{i}} \theta_{i j} \Delta y_{i t-j}+\varepsilon_{i t}
$$

If the series in the panel is not independent, the critical values will be invalid. Because of the relationship between data, Maddala and $\mathrm{Wu}$ (1997) gauged the critical values by the bootstrap method. The first advantage of the two tests used in this study is computing particular (ZORT) value for each unit. Secondly, the size of the time series has not to be equal for each unit. The third and last advantage of using these IPS and Fisher Tests is ADF test can use different lag values.

\subsection{Panel Cointegration Test}

The cointegration concept was first coined by Granger (1980). Cointegration implies the long-term correlation between the economic variables. The primary principle of the cointegration is about whether two or more variables are cointegrated. In other words, if the variables are cointegrated, they will move together in time so short termed complexities will be fixed in the long run. This means that the series will converge to each other, and the distance between sets will be stable in the long term.

Otherwise, if the two variables are not cointegrated, they could divert from each other irregularly (Dickey et al., 1991).

In case the panel unit root exists panel cointegration method must be used to disclose the long term relation. In the literature, one of the most utilized panel cointegration test is Pedroni (1995-1997) cointegration test. This test allowing heterogeneity in the cointegration vector is not only let the dynamics and the fixed effects are different between the sections of the panel but let the cointegrated vector is different between the sections under the alternative hypothesis as well.

In this study, Pedroni (1997) test has been used for heterogeneous panel cointegration test. All of the tests offered by Pedroni (1997) attained by the residuals from an equation below;

$$
\varepsilon_{i, t}=p_{i \varepsilon} \varepsilon_{i,(t-1)}+w_{i t} \quad y_{i t}=\alpha_{i}+\sum_{j=i}^{m} \beta_{j i} X_{j i t}+\varepsilon_{i t}
$$


In the equation above, $\mathrm{T}$ represents the number of observations, $\mathrm{N}$ represents the sum of cross-sections in the panel, and $\mathrm{M}$ represents the number in regression. On the grounds that there are $\mathrm{N}$ units different sections, there will be $\mathrm{N}$ units distinctive involving $\mathrm{M}$ units regressor each. $\beta_{1 i}, \beta_{2 i}, \ldots, \beta_{M i}$ Slope coefficients can vary between the cross-sections in the panel. $\alpha_{i}$ parameter is the fixed effect parameter peculiar to sections in a panel that could be different between the fixed and unit effects. Even if it is ignored most of the times, $\delta_{i t}$ deterministic time trend term peculiar to sections in a panel can be attached to an equation. Since the critical and asymptotic values can be affected by whether fixed effects and time trends are put into an equation peculiar to sections, the critical values peculiar to every each case were calculated by Pedroni (1999).

Null hypothesis tests whether $p_{i}$ bears integrity. Pedroni's four of different seven tests offered against the null hypothesis that is there is no cointegration are panel cointegration statistics, and rest of them are panel cointegration statistics of group average.

First three tests of four tests in the first category are nonparametric tests. The first test is such statistics similar to the variance ratio. Second and third ones are similar to Phillips Perron (rho) and t-statistics, respectively. Finally, the fourth one is similar to the ADF test statistic. While the first of three tests in the second category is related to PP (rho), the rest of them are identical to ADF ( $\mathrm{t}$ ) and $\mathrm{PP}(\mathrm{t})$. The comparative advantages of the mentioned statistics vary to a data formation process to a large extent. According to Pedroni (1997) examining the small sample features with Monta Carlo Simulation, group ADF $(\mathrm{t})$ and panel ADF $(\mathrm{t})$ statistics are more available if the period is less than twenty (Kök and Simsek, 2006).

Pedroni $(1996,2000)$ recommended Fully Modified Ordinary Least Squares (FMOLS) estimating the relations of cointegration determined by cointegration tests. This Pedroni's method, allowing a heterogeneity among the sections to a large extent, takes the existence of the potential correlation of constant term, error term, and independent variable into consideration. In this method, nonparametric adaptation is implemented to a dependent variable to fix the autocorrelation and endogeneity. Estimated long term parameters are acquired the way that the dependent variable is regressed over the independent variable. By the same token in this method, the long term coefficients of the average group FMOLS are acquired by averaging the group estimates, and corresponding t-statistics converge asymptotically standard normal distribution. Pedroni (2000) examined the robustness of FMOLS also in small samples and put forward that the performance of $t-$ statistics with Monte Carlo Simulation in small samples are robust.

In the model expressed as the equation (1), coefficients take different values for different units in different periods. In such these circumstances that 
the number of estimated parameters surpasses observation hence model cannot be predicted. Due to this advantage, in the studies performed by panel data are acquired different models by supposing different assumptions with regard to the features of error corrections and variability of coefficients. The models acquired by different assumptions are fixed and random effects models. Both in two models, it is assumed that the $e_{i t}$ errors are distributed as $N\left(0, \sigma_{e}^{2}\right)$ independently for all periods and units (Griffits, 1993; 571-573).

\subsection{Fixed Effects Model}

In panel data studies the way of integrating the variance resulting in differences among the units and the differences among the groups in time within a model is to suppose that current deviation entails changing in some or whole of the coefficients of the regression model. The model in which coefficients are assumed to be replaced by units or units and time is called fixed effects models. The general formulation of the model supposes that the differences in groups can be caught by the differences in fixed terms. To this end, a panel data model is estimated with a dummy variable.

$$
\beta_{1 i t}=\beta_{1} ; \beta_{2 i t}=\beta_{2} ; \beta_{3 i t}=\beta_{3}
$$

In the equation above, while only fixed parameter changes, fixed term differs not to based on time but to based on sections. Put it differently; It is stated that, although the time dimension is kept by fixed terms, it varies by the behavior among the groups. In other words, equation (1) will be just like equation (11).

$$
\begin{aligned}
& Y_{i t}=\beta_{1 i}+\beta_{2 i} X_{2 i t}+\ldots+\beta_{k i} X_{k i t}+e_{i t} \\
& Y_{i t}=\beta_{11} D_{1 i}+\beta_{12} D_{2 i}+\ldots+\beta_{1 N} D_{N i}+\beta_{2 i} X_{2 i t}+\ldots+\beta_{k i} X_{k i t}+e_{i t} \\
& =\sum_{j=1}^{N} \beta_{1 j} D_{j i}+\sum_{k=2}^{K} \beta_{k} X_{k t}+e_{i t}
\end{aligned}
$$

In the equation above, there are $(\mathrm{N})$ units groups and $(\mathrm{K}-1)$ units explanatory variables,

$$
\mathrm{D}_{1 \mathrm{i}}=\left\{\begin{array}{ll}
1, & \mathrm{i}=1 \\
0, & \text { Diğer Durumlar }
\end{array} \quad, \ldots \ldots \ldots, \quad \mathrm{D}_{1 \mathrm{~N}}= \begin{cases}1, & \mathrm{i}=\mathrm{N} \\
0, & \text { Diğer Durumlar }\end{cases}\right.
$$

Since there are no fixed coefficients that take place in this model. The differences in $\mathrm{N}$ units group will be examined by $\mathrm{N}$ units dummies.

\subsection{Random Effects Model}

In panel studies, while it is possible to investigate the change resulting from groups or groups and period, it is also examined by using the Random Effects Model. In a Random Effects Model, ups and downs resulting in units or units and time are attached within a model as a component of an error term. The primary reason for performing this is to try to preclude of losing degree of freedom encountered in fixed effects models (Baltagi, 1995: 13). Because in a random effects model it is not vital to get the coefficients 
peculiar to unit or unit and time, but it is crucial to get the coefficients peculiar to unit or unit and time. Besides, in a random effects model, the section in an examined sample does not only take the effects of differences arisen from groups and time into account but also takes the impact of variations on out of sample into consideration (Greene, 2003). Random Effects Model can be defined as follows;

$$
\begin{aligned}
\beta_{1 i}= & \overline{\beta_{1}}+\mu_{i} \\
& \overline{\beta_{1}} \text { is a constant of an average universe and unknown parameter. } \mu_{i},
\end{aligned}
$$

is unobservable random errors that take individual differences into account in individual behaviors. $\mu_{i}$ values are independent of each others and $e_{i t}$. When the equation 13 is placed in model 11.;

$$
\begin{aligned}
Y_{\mathrm{itt}} & =\left(\bar{\beta}_{1}+\mu_{\mathrm{i}}\right)+\beta_{2} \mathrm{X}_{2 \mathrm{it}}+\ldots+\beta_{\mathrm{k}} \mathrm{X}_{\mathrm{kit}}+\mathrm{e}_{\mathrm{it}} \\
& =\bar{\beta}_{1}+\sum_{\mathrm{k}=2}^{\mathrm{K}} \beta_{\mathrm{k}} \mathrm{X}_{\mathrm{kit}}+\left(\mathrm{e}_{\mathrm{it}}+\mu_{\mathrm{i}}\right)
\end{aligned}
$$

The equation above is the generalized form of the error component model. The equation above is the generalized form of the error component model. The exposition of "error component" arisen from $e_{i t}+\mu_{i}$ terms. This term is consisting of two components: While $e_{i t}$ points out the whole errors, $\mu_{i}$ "individual specific error" points out the individual differences according to constant time,

\subsection{Hausman Test}

Testing the hypothesis of "Error term components of the random effects model is unbound to the independent values in the model" can be examined by the Hausman Test (Greene, 2003). In this case, it is required to test whether the difference between the parameter estimators of the fixed effects model and the parameter estimators of the random effects model is statistically significant. The Hausman Test is used for preferring one of these two tests. Hausman test statistic shows the $(\mathrm{k})$ degree of freedom chi-square distribution for the hypothesis of "The estimator of random effects is true" in the context of the null hypothesis.

\section{Ampirical Findings}

The empirical relationship between the divorce and unemployment rates has been tried to analyzed by using Panel unit root test findings, panel cointegration test, The final regression test for Fixed Effects Model, LR Heteroskedasticity Test, and Wooldridge Autocorrelation Test.

\subsection{The Analysis Of Panel Unit Root Test}

According to Table 1 Hereunder, while Breitung, Im, Pesaran and Shin, ADF and Chi-Square test statistics are reporting "non-stationary" for 
unemployment value at level, Levin, Lin and Chu and Hadri test statistics are reporting that the series is stationary at level.

Table 2. Unit Root Test Findings (Level and First Differences)

\begin{tabular}{|l|l|l|l|l|}
\hline \multirow{2}{*}{ Panel Unit Root Tests } & \multicolumn{4}{|c|}{ (Unemployment) } \\
\cline { 2 - 5 } & Stat. I(0) & Probability I(0) & Test StatI(1) & Prob. I(1) \\
\hline Levin, Lin \& Chu & 1,65387 & 0.9509 & -16.3090 & 0.0000 \\
\hline Breitung $t$-stat & 1,53207 & 0,9372 & -4.44253 & 0.0000 \\
\hline Im, Pesaran and Shin W-ist & 0.63845 & 0,7384 & -1.45768 & 0.0725 \\
\hline ADF - Fisher Chi-square & 68,1593 & 0,4037 & 85.2669 & 0.0025 \\
\hline PP - Fisher Chi-square & 43,8425 & 0,9838 & 97.2196 & 0.0001 \\
\hline Hadri Z ist. & 10,1663 & $0.0000 \quad 37.2312$ & 0.0000 \\
\hline Panel Unit Root Tests & \multicolumn{4}{|c|}{ (Growth) } \\
\cline { 2 - 5 } & Stat. I(0) & Probability I(0) & Test StatI(1) & Prob. I(1) \\
\hline Levin, Lin \& Chu & $-11,4903$ & 0.0000 & -10.9391 & 0.0000 \\
\hline Breitung -stat & $-3,60425$ & 0.0000 & -3.36568 & 0.0004 \\
\hline Im, Pesaran and Shin W-ist & $-10,5822$ & 0.0000 & -0.65344 & 0.2567 \\
\hline ADF - Fisher Chi-square & 224,711 & 0.0000 & 68.6232 & 0.0610 \\
\hline PP - Fisher Chi-square & 315,874 & 0.0000 & 84.2566 & 0.0031 \\
\hline Hadri Z ist. & 10.8979 & 0.0000 & 21.8682 & 0.0000 \\
\hline
\end{tabular}

When the first difference of unemployment value is taken, all of the tests except for Im, Paseran and Shin, PP and Chi-Square report the series is stationary.

As to growth variable, the tests except for Im, Pesaran and Shin, PP and Chi-Square are reporting stationary. When the first difference of the series is taken, Im, Pesaran and Shin and ADF Chi-Square test statistics point out the unit root; others report the stable condition.

\subsection{Panel Kointegrasyon Test Analysis}

After the stage examined the stationary of the series, it is passed to another step, panel cointegration analysis, testing the long term relationship between the series by applying Pedroni, Kao, and Johansen Fisher tests.

Tablo 3. Panel Cointegrasyon Test Results

\begin{tabular}{|c|c|c|c|c|}
\hline \multicolumn{5}{|c|}{ Growth $_{i t}=\propto_{i t}+$ Bunemployment $_{i t}+u_{i t}$} \\
\hline \multicolumn{5}{|c|}{ Pedroni Panel Cointegrasyon Test Result } \\
\hline \multicolumn{5}{|l|}{ (Within-Dimension) } \\
\hline & t Stat. & Prob. & $\begin{array}{l}\text { Weighted } t \\
\text { Stat. }\end{array}$ & Prob. \\
\hline Panel v-Statistic & $-1,977770$ & 0,9760 & -5.339362 & 1.0000 \\
\hline Panel rho-Statistic & $-4,652487$ & 0.0000 & -4.796302 & 0.0000 \\
\hline Panel PP-Statistic & $-11,47621$ & 0.0000 & -12.38322 & 0.0000 \\
\hline Panel ADF-Statistic & $-11,74344$ & 0.0000 & -12.41979 & 0.0000 \\
\hline \multicolumn{5}{|l|}{ (Between Dimension) } \\
\hline & $t$ Stat. & Prob. & & \\
\hline Group rho-Statistic & -1.411484 & 0.0791 & & \\
\hline Group PP-Statistic & -11.49365 & 0.0000 & & \\
\hline Group ADF-Statistic & -11.59055 & 0.0000 & & \\
\hline \multicolumn{5}{|c|}{ Kao Panel Cointegrasyon Test Result } \\
\hline \multirow{2}{*}{\multicolumn{3}{|c|}{$A D F$}} & t Stat. & Prob. \\
\hline & & & -9.525056 & 0.0000 \\
\hline \multicolumn{3}{|l|}{ Residual variance } & 9.920890 & \\
\hline \multicolumn{3}{|l|}{ HAC variance } & 3.886607 & \\
\hline
\end{tabular}


Ahmet Tayfur Akcan \& Kubilay Çağrı Yllmaz \& Volkan Alptekin / Analyzing Relationship Between Unemployment and Growth For Selected OECD Countries Through Panel Data

\begin{tabular}{|l|l|l|l|l|}
\hline \multicolumn{5}{|c|}{ Johansen Fisher Panel Cointegrasyon Test } \\
\hline $\begin{array}{l}\text { Hypothesized } \\
\text { No. of CE }(s)\end{array}$ & $\begin{array}{l}\text { Fisher Stat. } * \\
\text { (from trace test })\end{array}$ & Prob. & $\begin{array}{l}\text { Fisher Stat. } \\
\text { (from max } \text {-eigen } \\
\text { test })\end{array}$ & Prob. \\
\hline None & $\mathbf{3 0 5 . 6}$ & 0.0000 & $\mathbf{2 4 8 . 6}$ & 0.0000 \\
\hline At most 1 & 192.9 & 0.0000 & 192.9 & 0.0000 \\
\hline
\end{tabular}

As for Pedroni test findings, the null hypothesis of "there is no cointegration between series." rejected by rho_Statistics and Panel v_Statistics. It is accepted that the long term relationship between series is apparent. According to the findings of Another test Kao examining the long term relationship, the null hypothesis about whether there is no long period relationship between series has been rejected and put differently; the long term relationship has been accepted. According to the empirical findings of Johansen Fisher Cointegration Test, the null hypothesis has been rejected and the alternative accepted.

When the results of cointegration tests are evaluated as a whole, it is reported that the long term relationship between divorce and unemployment values for 33 OECD member countries.

\subsection{The Estimation Of Fixed Effect Panel Data Regression}

In this study, it is assumed that the ultimate regression model will be more consistent if fixed effects for cross-section part and random effects for the period are used.

Tablo 4. Panel Veri Regression Estimation Results

\begin{tabular}{|l|l|l|l|l|}
\hline & \multicolumn{1}{|c|}{ Coef. } & \multicolumn{1}{|c|}{ Standart Error } & \multicolumn{1}{|c|}{ T-Stat. } & \multicolumn{1}{c|}{ Prob. } \\
\hline Unemployment & -0.179231 & 0.041590 & -4.309505 & 0.0000 \\
\hline C & 3.832862 & 0.323367 & 11.85299 & 0.0000 \\
\hline $\boldsymbol{R}^{2}: 0,166385$ & D.W. İst: $\mathbf{1 , 2 9 8 8 6 4}$ & $\begin{array}{l}\text { F-Ist.: 6,394170 } \\
(0.000000)\end{array}$ \\
\hline
\end{tabular}

In this study, it is assumed that the ultimate regression model will be more consistentif fixed effects for cross-section part and random effects for the period are used.

When focused on the results of the final model, the very first attention getter is Durbin Watson test statistics. This statistics is expected to be around two. If Durbin- Watson test statistics gets smaller than one, it is going to point out that there is a severe risk for a model in terms of stability. If the DW test statistic is around two, it means that there is no such autocorrelation handicap for the model. According to the empirical findings which take place in table 1, it can be seen even if the DW statistics is not so much worse, but it needs to get adjusted. This is because the lag of dependent value is attached within a model to get rid of the handicap of autocorrelation. Accordingly ultimate model will be as below;

Tablo 5. Panel Veri Regression Estimation Results (Ultimate)

\begin{tabular}{|l|l|l|l|l|}
\hline & Coef. & 9Standart Error & T-Stat. & Prob. \\
\hline GROWTH(-1) & 0.302519 & 0.032850 & 9.209023 & 0.0000 \\
\hline UNEMPLOYMENT & -0.114929 & 0.037441 & -3.069578 & $\mathbf{0 . 0 0 2 2}$ \\
\hline C & 2.681021 & 0.321574 & 8.337175 & 0.0000 \\
\hline
\end{tabular}


When the empirical outputs evaluated by table four, it is evidently seen that the model does not bear the autocorrelation problem, and it is more robust ever. According to the ultimate findings of table three, since the probability value of the unemployment variable $(0.0022)$ is smaller than the table value (0.05), it is supported that the series of unemployment affects the set of growth. As it has to be examined whether the model bears an autocorrelation and heteroskedasticity, it is deployed Hetoreskedasticity LR (Greene, 2003) and Wooldridge (2003) Autocorrelation Tests, respectively. The hypothesis peculiar to these tests is as below;

$\mathrm{H}_{0}$ : There is no heteroskedasticity or autocorrelation

$\mathrm{H}_{1}$ : There is heteroskedasticity or autocorrelation

Tablo 6. Heteroskedasticity LR ve Wooldrige Tipi Autocorrelation Tests

\begin{tabular}{|c|c|c|}
\hline Test & Test Stat. & Critical Value (0.05) \\
\hline LR Test & 23.16 & 37.65 \\
\hline Wooldrige Test & 1.25 & 4.33 \\
\hline
\end{tabular}

When focused on table 5, it is seen that the null hypothesis can not be rejected, so it is evident that the model does not under the risks of heteroskedasticity and autocorrelation.

\section{CONCLUSION}

The eventual model without involving autocorrelation and heteroskedasticity reveals unemployment series has an impact on the growth series due to the fact that the probability of the unemployment variable $(0.0022)$ is smaller than the five percent of critical value. There are some robust checks in the final part of the study, such as LR Heteroskedasticity and Wooldridge Autocorrelation tests as regard to structural consistency. These checks confirm that the ultimate model does not bear econometrical difficulties. This study demonstrates almost the same picture in comparison to most of the other studies in the literature. However, there are some different points with the rest of them which are emerging from the sample size and methodology.

As a conclusion the final model, reinforced by LR Heteroskedasticity and Wooldridge Autocorrelation tests, supports the hypothesis that the unemployment series affects the growth series. According to the empirical findings of the study, it is reported that unemployment impact on growth. The literature in this area what the differences between this study and the others are sample size and methodology.

\section{REFERENCES}

Abdel-Raouf, F., (2014). "On The Stability of Okun's Law: Evidence From The Great Recession of 2007-2009", The Journal of Business and Economic Studies, 20(1), 7595

Anderton, R. Aranki, T., Bonthuis, B. ve Valerie, J. (2014), "Disaggregating Okun's Law Decomposing the Impact of The Expenditure Components of GDP on Euro Area Unemployment", European Central Bank Jworking Paper Series No: 1747, December, 1-24 
Ahmet Tayfur Akcan \& Kubilay Çă̆rı Yllmaz \& Volkan Alptekin / Analyzing Relationship Between Unemployment and Growth For Selected OECD Countries Through Panel Data

Ar1 A. (2016), "Türkiye'deki Ekonomik Büyüme ve İşsizlik İlişkisinin Analizi: Yeni Bir Eşbütünleşme Testi”, Siyaset, Ekonomi ve Yönetim Araştırmaları Dergisi, 4(4), 5767.

Ball, L., Furceri, D., Leigh, D. ve Loungani, P. (2016), "Does One Law Fit All? Cross-Country Evidence on Okun's Law", September 2016 Preliminary Draft, http://unassumingeconomist.com/wp-content/uploads/2016/08/crosscountryevidenceon-okun-sep-2016-paris-workshop-draft-with-tables-and-charts.pdfe.t. 04/07/2018.

Baltagi, B. (1995). Econometric Analysis of Panel Data. New York: John Wiley \& Sons. Inc.

Baltagi, B., (2001), Econometric Analysis of Panel Data, Chichester, Eng.: John Wiley and Sons Inc.

Barışı, S., Çevik, E.İ. ve Çevik, N.K. (2010) “Türkiye’de Okun Yasası, Asimetri İlişkisi ve İstihdam Yaratmayan Büyüme: Markov-Switching Yaklaşımı” Maliye Dergisi, 159, 88-102

Bentzen J. Smith V. (2002), “An Empirical Analysis Of The Effect Of Labor Market Characteristic On Marital Dissolution Rates", Department Of Economic Working Paper Series, No:2002:14

Blekesaune, M. (2008), "Unemployment and Partnership Dissolution, Norvegian Social Research (NOVA)", Economic and Social Research Council, 1-17"

Ceylan, S. ve Şahin, B. Y. (2010) "İşsizlik ve Ekonomik Büyüme İlişkisinde Asimetri” Doğuş Üniversitesi Dergisi, 11 (2): 157-165.

Dickey, D. A., Jansen, D. W. ve Thornton, D. C.; (1991)., "A Primer on Cointegration with An Application to Money and Income", Review Federal Reserve Bank of ST. Louis, 73 (2), 58-78.

Economou, A., ve Psarianos, I. N. (2016). "Revisiting Okun's Law in European Union Countries" Journal of Economic Studies, 43(2), 275-287.

Eğri, T. (2018), "İşsizlik ve Ekonomik Çıktı İlişkisi: Mısır İçin Okun Yasası Analizi”, Yaşar Üniversitesi Dergisi, 13(49), 68-78

Erkuş, S., Gemrik, S. ve Aytemiz L. (2016), “Türkiye'de Büyüme ve İşsizlik İlişkisi: Okun Yasasının Asimetrik Analizi”, Scientific Cooperation Fort He Future in Social Sciences International Conference - 2016, 22-23 Eylül Uşak, 135-141

Eryiğit, P., Cura, S., Züngün, D. ve Ortanca, M. (2014), "Econometric Evaluation of The Relationship Economic Growth and Unemployment in EU \& Turkey", Annals of The University of Oradea, Economic Science Series, 23(1), 452-461

Eser Yılmaz B. (2014), "Ekonomik Büyüme ve İşsizlik İlişkisi: Türkiye Örneği”, TİSK Akademi, 2, 26-47

Fouquau, J. (2008), “Threshold Effects in Okun's Law: A Panel Data Analysis”, Economic Bulletin, 5(33), 1-14

Göçer, İ. (2015), "Okun Yasası: Türkiye Üzerine Bir Uygulama”, Uluslararası Ekonomik Araştırmalar Dergisi, 1(1), 1-12

Göçer, İ. ve Gerede, C. (2016), "Cari Açık - Ekonomik Büyüme - Enflayon ve İşsizlik Açmazında Türkiye: Yeni Nesil Bir Ekonometrik Analiz”, Anadolu Üniversitesi Sosyal Bilimler Dergisi, Kasım Özel Sayısı, 35-46

Gray J.S, (1995) "The Causality Between Employment and Divorce", Family Economics and Resources Managament Biennial, 171-176.

Greene, W.H. (2003), Econometric Analysis, Prentice Hall, New Jersey.

Griffits, W. E. R \& Carte H. (1993). Learning and Practicing Econometrics, John Wiley, New York

Hansen, H.T., (2005), "Unemployment and Marital Dissolution: A Panel Data Study Of Norway", European Sociological Review, 21(2): 135-148

Hooper, V. (2017). "Okun's Law Revisited Within The Context of High Eurozone Unemployment: A Note". E-Journal of International and Comparative Labour Studies, 6(2). 2-4

Hsiao C. (1986) Analysis of Panel Data, Cambridge University Press 
Hsiao, C. (2003). Analysis of Panel Data. New York: Cambridge University Press.

Huang, T.(2003), "Unemployment and Family Behaviour In Taiwan", Journal Of Family and Economic Issues24(1), 27-48.

Im, K. S., H., Pesaran ve Y., Shin (2003), "Testing for unit roots in heterogeneous panels", Journal of Econometrics, 115, p. 53- 74.

Jensen P., Smith N, (1990), "Unemployment and Marital Dissolution", Journal of Population Economics, 215-229.

Kaljmin M, Graaf P. M., (2004), Interactions Between Culturel and Economic Determinants of Divorce In The Netherlands", Journal of Marriage and Family, 66: 75-89.

Kanca, O. C. (2012), "Türkiye'de İşsizlik ve İktisadi Büyüme Arasındaki Nedenselliğin Ampirik Bir Analizi”, Çukurova Üniversitesi, Sosyal Bilimler Enstitüsü Dergisi, 21(2), 1-18

Kawata, Y. (2008), "Does High Unemployment Rate Result In A High Divorce Rate? A Test For Japan", Revista de economiadel Rosario, 11(2): 149-164.

Kök, R. (2006), "Endüstri-içi Dıs Ticaret, Patentler ve Uluslararası Teknolojik Yayılma", UEK-TEK 2006 Uluslararası Ekonomi Konferans1, Türkiye Ekonomi Kurumu, Ankara, 11-13 Eylül 2006.

Köse Z. (2016), “Türkiye Ekonomisinde 2003-2014 Döneminde Ekonomik Büyüme İşsizlik ve Enflasyon İlişkisi” Türk Sosyal Bilimler Araştırmaları Dergisi, 1(1), 58-76

Levin, A., ve C. Lin (1992), "Unit root tests in panel data: asymptotic and finitesampleproperties",University of California, San Diego Working Paper,p. 23-92.

Levin, A., ve C. Lin (1993), "Unit root tests in panel data: new results", University of California, San Diego Working Paper, p.56-93.

Maddala, G. S. ve S. WU, (1997), "Comparative Study of Unit Root tests with Panel Data and a New Simple Test", Oxford Bulletin of Economics and Statistics, 61, 631-652.

Okun, A. M. 1962; "Potential GNP: Its Measurement and Significance", American Statistical Association Proceedings of The Business and Economic Statistics Section. 98-104

Pınar, A., Siverekli E. Ve Demir M., (2016), "Şanlıurfa'da İşverenlerin ve İşçilerin Suriyeli İstihdamına Bakışı”, Uluslararası Çalışma Örgütü Araştırma Raporları, 1-34

Pedroni, P. (1995), "Panel Cointegration; Asymptotic and Finite Sample Properties of Pooled Time Series Tests, With an Application to the PPP Hypothesis," Indiana University Working Papers In Economics, No. 95-013, June.

Pedroni, P. (1997), "Panel Cointegration; Asymptotic and Finite Sample Properties of Pooled Time Series Tests, With an Application to the PPP Hypothesis: New Results," Indiana University Working Papers In Economics, April.

Pedroni, P. (1999), "Critical Values for Cointegration Tests in Heterogeneous Panels with Multiple Regressors", Oxford Bulletin Of Economics and Statistics, Special Issue, 653-70.

Reaymaeckers, P. (2006), "Marriage and Divorce In Belgium: The Influence Of Professional, Financial and Educational Resources On The Risk For Marriage Dissolution", Journal Of Divorce and Remarriage, 46(1/2), 151-174.

Roy, S. (2010), "Unemployment Rate and Divorce" The University Of Melbourne Institute Working Paper

Sandalcılar, A.R., "İşsizlik Boşanmayı Etkiliyor mu? Bölgesel Panel Nedensellik", Ege Akademik Bakış, Cilt: 2, Sayı:2, ss:225-238.

South, S.J., (1985), "Economic Conditions and Divorce Rate: A Time Series Analysis Of The Postwar US", Journal of Marriage and The Family, 47(1), 31-41.

Svaver, M. (2002), "Determinants Of Divorce In Denmark", department of Economics Working Paper Series, No:2002:19

Tatoğlu, F. Y. (2011), "The Long and Short Run Effects Between Unemployment and Economic Growrth in Europe", Doğuş Üniversitesi Dergisi, 12(1), 99-113

Thomas, L.E, (1980), "Unemployment and Family Stress: A Reassesment", Family Relations, 29(4), 517-524. 
Ahmet Tayfur Akcan \& Kubilay Çă̆r Yllmaz \& Volkan Alptekin / Analyzing Relationship Between Unemployment and Growth For Selected OECD Countries Through Panel Data

Uras, Ö. (2016), “Türkiye Ekonomisindeki İstihdamsız Büyümenin Ekonometrik Analizi”, İstanbul Üniversitesi İktisat Fakültesi Ekonometri ve İstatistik Dergisi, 24, 94-108

Uysal, D. ve Alptekin, V. (2009), "Türkiye Ekonomisinde Büyüme - İşsizlik İlişkisinin Var Modeli Yardımıyla Sinanması (1980 - 2007)”, Dumlupınar Üniversitesi Sosyal Bilimler Dergisi, 25, 69-78

Yüceol H. M., (2006), “Türkiye Ekonomisinde Büyüme ve İşsizlik İlişkisinin Dinamikleri”, İktisat İşletme ve Finans, 21(243), 81-95

Yüksel, S. ve Oktar, S. (2017), "Okun Yasasının Farklı Gelişme Düzeyindeki Ülkelere İlişkin Ekonometrik Analizi”, Marmara Üniversitesi İktisadi ve İdari Bilimler Dergisi, 39(1), 323-332 